九州大学学術情報リポジトリ

Kyushu University Institutional Repository

\title{
Electro Protoplast Fusion between Solanum sisymbri ifolium and Other Solanum Species
}

Oda, Naok i

Faculty of Agriculture, Kyushu Unviersity

Isshiki, Shiro

Faculty of Agriculture, Kyushu Unviersity

Sadohara, Takeshi

Faculty of Agriculture, Kyushu Unviersity

Ozaki, Yukio

Faculty of Agriculture, Kyushu Unviersity

他

https://doi.org/10.5109/4712

出版情報：九州大学大学院農学研究院紀要. 51 (1)，pp.67-72，2006-02-01. Faculty of Agriculture， Kyushu University

バージョン：

権利関係： 


\title{
Electro Protoplast Fusion between Solanum sisymbrifolium and Other Solanum Species
}

\author{
Naoki ODA ${ }^{1}$, Shiro ISSHIKI ${ }^{2}$, Takeshi SADOHARA ${ }^{1}$, Yukio OZAKI ${ }^{3 *}$ \\ and Hiroshi OKUBO
}

\author{
Laboratory of Horticultural Science, Division of Agricultural Botany, Department of Plant Resources, \\ Faculty of Agriculture, Kyushu University, Fukuoka 812-8581, Japan \\ (Received October 28, 2005 and accepted November 16, 2005)
}

\begin{abstract}
Symmetric or asymmetric protoplast fusions between Solanum sisymbriifolium and other Solanum species (S. integrifolium and $S$. toxicarium) were performed to obtain the perfectly soil-borne disease resistant rootstocks for eggplant cultivation. Somatic hybrid was not obtained from symmetric fusion in selective media, where one parent's protoplasts formed colonies and the other did not. Combining of iodoacetamide-induced inactivation of $S$. integrifolium and no cell division ability of $S$. sisymbriifolium on a selective medium in asymmetric fusion, the hybridity of two calli was elucidated by analyzing IDH, PGM and SKDH isozymes. Plant regeneration from the somatic hybrid calli was also successful, but the regenerated plants did not show the hybridity. The result may be caused by the elimination of $S$. integrifolium chromosomes during the process of shoot regeneration from calli.
\end{abstract}

\section{INTRODUCTION}

Somatic hybridization is a technique that allows the manipulation of cellular genomes by protoplast fusion. Its major contribution to plant breeding is in overcoming common crossing barriers among plant species and in organelle genetics and breeding.

Solanum sisymbriffolium Lam., a wild American species, shows resistance to root-knot nematodes (Fassuliotis and Bhatt, 1982), carmine spider mites (Schalk et al., 1975) and a few races of bacterial wilt (Ali et al., 1990). In addition, this species is not susceptible to low temperature, and fruit yield of eggplant grafted on this species is higher than that on eggplant (Ali, 1991). It is, however, not easy to prepare this species as a rootstock because of existing spines on its stems and leaf veins.

Solanum integrifolium is a source of genes for resistance to Fusarium wilt (Yamakawa and Mochizuki, 1979) and mite Tetranychus urticae (Rotino et al., 1992). According to our previous experiment, this species showed rapider growth than other wild Solanum species such as $S$. indicum L., S. torvum Swartz, S. sisymbriifolium and $S$. toxicarium. Although it is also currently used as rootstock in eggplant cultivation in Japan (Okimura et al., 1986), it is susceptible to root-knot nematodes and a few races of bacterial wilt (Mochizuki and Yamakawa, 1979; Ali et al., 1990).

\footnotetext{
1 Laboratory of Horticultural Science, Department of Agronomy, Faculty of Agriculture, Kyushu University, Fukuoka 812-8581, Japan

${ }^{2}$ Laboratory of Biotechnology and Plant Breeding, Department of Applied Biological Sciences, Faculty of Agriculture, Saga University, Saga 840-8502, Japan

${ }^{3}$ Laboratory of Agricultural Ecology, Division of Agricultural Ecology, Department of Plant Resources, Faculty of Agriculture, Kyushu University, Fukuoka 811-2307, Japan

* Corresponding author (E-mail: ozaki@farm.kyushu-u.ac.jp)
}

Solanum toxicarium has perfect resistance to all above-mentioned diseases (Yamawaka and Mochizuki, 1979; Ali et al., 1990; Ali, 1991). But in eggplant on this species, the growth is very slow and the fruit quality is very poor. Moreover, this species is susceptible to low temperature (Ali, 1991).

Although interspecific cross seems to be the most appropriate method to combine resistant genes of wild species, three wild Solanum species, $S$. sisymbriifoli$u m, S$. integrifolium and $S$. toxicarium, are perfectly cross incompatible to each other (Nishio et al., 1984; Ali and Fujieda, 1990; Ali, 1991).

Establishment of the protoplast culture system of the fusion parents is required for the production of somatic hybrids. Methods for protoplast culture and plant regeneration in $S$. integrifolium and $S$. toxicari$u m$ have been established (Sadohara, 1993; Sadohara et $a l ., 1993$ ) and those in $S$. sisymbriffolium (Oda et al., 2006) were reported in the previous paper. This study was undertaken to obtain the perfectly desirable characters, e.g., multiple resistance to all the diseases, spinelessness, tolerance to low temperature and high quality and yield, by using somatic hybridization between $S$. sisymbriifolium and $S$. integrifolium and between $S$. sisymbriffolium and $S$. toxicarium).

\section{MATERIALS AND METHODS}

Symmetric protoplast fusion between $S$. sisymbriifolium and other Solanum spp.

\section{Plant materials}

Seeds of S. sisymbriffolium, $S$. integrifolium and $S$. toxicarium were surface sterilized with sodium hypochlorite solution ( $2 \%$ active chlorine) for $20 \mathrm{~min}$ and washed three times with sterilized water. They were aseptically sown in $200 \mathrm{ml}$ conical flasks containing $40 \mathrm{ml}$ of MS medium (Murashige and Skoog, 1962) supplemented with $1 \%$ sucrose and $0.25 \%$ gellan gum, and incubated in the growth cabinet $\left(30 \mu \mathrm{E} / \mathrm{m}^{2} \cdot \mathrm{s}, 16 \mathrm{~h} /\right.$ day at 
Table 1. Components of media used for protoplast culture.

\begin{tabular}{ccccccc}
\hline Medium & Mineral salts & $\begin{array}{c}\text { Organic } \\
\text { components }\end{array}$ & NAA (mg/l) & $2,4-\mathrm{D}(\mathrm{mg} / \mathrm{l})$ & BA (mg/) & Kinetin (mg/l) \\
\hline A & Kao & Kao & 5.0 & 1.0 & 1.0 & 0 \\
B & $1 / 2 \mathrm{MS}$ & MS & 1.0 & 0 & 0 & 1.0 \\
$\mathrm{C}$ & $1 / 2 \mathrm{MS}$ & MS & 0.1 & 0 & 0 & 0.1 \\
\hline
\end{tabular}

$25^{\circ} \mathrm{C}$ ). Plants of $S$. toxicarium were subcultured by leafy node cutting on the fresh medium of the same composition with three weeks intervals. Leaves of $S$. sisymbriffolium, $S$. integrifolium and $S$. toxicarium were taken from 3-4, 2 and 6 week-old explants, respectively.

\section{Protoplast fusion}

Protoplasts were isolated as the same method in the previous report (Oda et al., 2006). 'The isolated protoplasts were suspended in fusion solution containing $0.225 \mathrm{M}$ glucose, $0.225 \mathrm{M}$ mannitol and $2.5 \mathrm{mM} \mathrm{CaCl}_{2}$. The density was adjusted to $2.0 \times 10^{5}$ protoplasts $/ \mathrm{ml}$. The protoplast suspensions of $S$. sisymbrifolium and $S$. integrifolium, or those of $S$. sisymbriffolium and $S$. toxicarium were mixed at a ratio of $1: 1(\mathrm{v} / \mathrm{v})$. The protoplast mixture were fused by means of electro fusion using a Somatic Hybridizer SSH-1 (Shimadzu Corp., Japan). A $0.8 \mathrm{ml}$ aliquot of mixed protoplast suspension was introduced into the fusion chamber FTC-03 (Shimadzu Corp., Japan), aligned with a voltage altering current of $40 \mathrm{~V}$, frequency of $1.0 \mathrm{MHz}$, voltage direct current of $150 \mathrm{~V}(750 \mathrm{~V} / \mathrm{cm}$ field strength), pulse width of $400 \mu$ s and pulse of 1-2 times. Following the fusion treatment, the protoplast suspension was transferred to $60 \times 15 \mathrm{~mm}$ petri dish and an equal volume of two-fold strength culture medium was added.

Protoplast culture

Fused protoplasts of $S$. sisymbriffolium and $S$. integrifolium were cultured in Kao medium containing $0.03 \mathrm{M}$ sucrose, $0.4 \mathrm{M}$ mannitol, $5.0 \mathrm{mg} / \mathrm{l} \mathrm{NAA}, 1.0 \mathrm{mg} / \mathrm{l}$ 2,4-D and $1.0 \mathrm{mg} / \mathrm{BA}$ (medium A; Table 1 ) or $1 / 2 \mathrm{MS}$ medium containing $0.03 \mathrm{M}$ sucrose, $0.4 \mathrm{M}$ mannitol, $1.0 \mathrm{mg} / \mathrm{l} \mathrm{NAA}$ and $1.0 \mathrm{mg} / \mathrm{l}$ kinetin (medium B) (Sadohara, 1993), and those of $S$. sisymbriffolium and $S$. toxicarium were cultured in medium A or a half strength MS medium containing $0.03 \mathrm{M}$ sucrose, $0.4 \mathrm{M}$ mannitol, $0.1 \mathrm{mg} / \mathrm{l} \mathrm{NAA}$ and $0.1 \mathrm{mg} / 1$ kinetin (medium C) (Sadohara, 1993; Sadohara et al., 1993). Protoplasts of both the fusion pairs were cultured in the dark at $30^{\circ} \mathrm{C}$ for the first seven days and thereafter placed at $25^{\circ} \mathrm{C}$ in the dark. Two $\mathrm{ml}$ of fresh media (same as each initial medium but modified with $0.2 \mathrm{M}$ mannitol) were added at an interval of 14 days.

Plant regeneration

Protoplast-derived calli of $1-3 \mathrm{~mm}$ in diameter (eight weeks after culture) were transferred to $100 \mathrm{ml}$ conical flasks containing $30 \mathrm{ml}$ of MS medium supplemented with $30 \mathrm{~g} / 1$ sucrose, $7.0 \mathrm{~g} / \mathrm{l}$ agar, $0.1 \mathrm{mg} / \mathrm{l} \mathrm{IAA}$ and $1.0 \mathrm{mg} / \mathrm{l}$ zeatin for shoot regeneration. This medium has been shown to be adequate for the regeneration of protoplast-derived calli of $S$. sisymbriffolium, $S$. integrifolium and $S$. toxicarium (Sadohara, 1993; Oda et al.,
2006). After four weeks of culture, regenerated plants were transferred for rooting on a half strength MS medium with $5.0 \mathrm{~g} / \mathrm{l}$ sucrose and $2.5 \mathrm{~g} / \mathrm{l}$ gellan gum.

Isozyme analysis

At the leaf regeneration stage, isozymes of the leaf of each plant were examined by starch gel electrophoresis. The gels were stained for isocitrate dehydrogenase (IDH; EC 1.1.1.41) and phosphoglucose dehydrogenase (PGD; 1.1.1.43) by means of the methods of Wendel and Parks (1982) and Wendel (1983).

Asymmetric protoplast fusion between $S$. sisymbriifolium and other Solanum spp.

Plant materials

Plant materials and the methods of protoplast isolation were identical to the previous experiment.

Iodoacetamide treatment

Protoplasts were treated with four levels of concentrations $(5.0,7.5,10.0$ and $12.5 \mathrm{mM})$ of iodoacetamide (IOA) solution containing $0.4 \mathrm{M}$ mannitol and $0.03 \mathrm{M}$ sucrose $(\mathrm{pH} 5.5)$ at $5^{\circ} \mathrm{C}$ for $10 \mathrm{~min}$. Then they were washed three times by centrifugation $(100 \times \mathrm{g}$, $3 \mathrm{~min}$ ) with culture medium. IOA-treated protoplasts of $S$. sisymbriifolium, $S$. integrifolium and $S$. toxicarium were cultured in media A, B and $\mathrm{C}$, respectively. Frequency of cell division was examined after ten days of protoplast culture.

Protoplast fusion, culture and plant regeneration

Protoplast fusion and regeneration were carried out by the same methods in the previous experiment. Selection of the fused heterokaryon protoplast from homokaryon or non-fused protoplast was performed by means of the combination of IOA inactivation and the difference in cell division ability in the selective media. Isozyme analysis

Samples were extracted from calli and leaves of regenerated plants. Isocitrate dehydrogenase (IDH), phosphoglucomutase (PGM; EC 2.7.5.1) and shikimate dehydrogenase (SKDH; EC 1.1.1.25) isozymes were stained according to the same methods in the previous experiment.

\section{RESULTS}

\section{Symmetric protoplast fusion between $S$. sisymbri- ifolium and other Solanum spp.}

The process of electro fusion took less than $2 \mathrm{~min}$ per dish. Pearl chains of 6-7 protoplasts formed within 50 seconds of an A.C. field application at $1.0 \mathrm{MHz}$ and $750 \mathrm{~V} / \mathrm{cm}$. Fusion between protoplasts occurred when D.C. square pulses were applied. The exposure of samples of protoplast mixture to a train of 2-3 D.C. pulses of 
Table 2. Effect of media on colony formation from protoplasts of $S$. sisymbriifolium and $S$. integrifolium and from fused protoplast mixture?

\begin{tabular}{lccc}
\hline \multicolumn{1}{c}{ Species } & Medium & $\begin{array}{c}\text { Volume of } \\
\text { protoplast } \\
\text { suspension }^{y}\end{array}$ & $\begin{array}{c}\text { No. of } \\
\text { colonies }\end{array}$ \\
\hline S. sisymbriffolium & $\mathrm{A}^{\mathrm{x}}$ & 2.0 & 7 \\
S. integrifolium & $\mathrm{B}$ & 2.0 & 0 \\
& $\mathrm{~A}$ & 2.0 & 0 \\
Fused protoplast mixture & $\mathrm{B}$ & 2.0 & 211 \\
& $\mathrm{~A}$ & 6.0 & 13 \\
& $\mathrm{~B}$ & 6.0 & 280
\end{tabular}

${ }^{2}$ Protoplasts obtained after electro protoplast fusion between S. sisymbriifolium and $S$. integrifolium.

${ }^{y}$ Protoplast density $=5.0 \times 10^{4} / \mathrm{ml}$.

${ }^{\star}$ See Table 1 .

$400 \mu$ s, each $750 \mathrm{~V} / \mathrm{cm}$, resulted in a fusion rate of $40-50 \%$. At least $20 \%$ of the fusion products were in the 1:1 (binary) category. The frequency of heterokaryons was not determined, since it was unable to distinguish protoplasts of one parent from those of the other parent. Solanum sisymbriifolium $(+) S$. integrifolium

Effect of media on colony formation from protoplasts in S. sisymbriifolium, $S$. integrifolium and fused protoplast mixture is shown in Table 2. Protoplast division was found only in $S$. integrifolium in medium B, whereas in medium A, it was observed only in $S$. sisymbriifolium. Colony formation of the fused protoplasts was observed in both media A and B.

The rates of shoot and root formation from the protoplast-derived calli in the fusion plates were similar to those of the control plates of $S$. sisymbriifolium or $S$. integrifolium parental protoplasts (Table 3).

Two hundred thirty eight shoots transferred to rooting medium were used for the analysis of isozyme patterns of IDH. The isozyme pattern of 28 shoots regenerated in medium $\mathrm{A}$ was all identical and it was the same as that of $S$. sisymbriifolium. All the regenerated shoots in medium $B$ exhibited the same isozyme pattern as the shoots of $S$. integrifolium (data not shown).

Solanum sisymbriifolium (+) S. toxicarium

Cell division and colony formation of the fused protoplasts were observed in both media A and C, whereas those of the both parents were not (Table 4). Compared
Table 4. Effect of media on colony formation from protoplasts of $S$. sisymbriifolium and $S$. toxicarium and from fused protoplast mixture ${ }^{z}$.

\begin{tabular}{llcc}
\hline \multicolumn{1}{c}{ Species } & Medium & $\begin{array}{c}\text { Volume of } \\
\text { protoplast } \\
\text { suspension' }\end{array}$ & $\begin{array}{c}\text { No. of } \\
\text { colonies }\end{array}$ \\
\hline S. sisymbriffolium & $\mathrm{A}^{\mathrm{x}}$ & 2.0 & 6 \\
S. toxicarium & $\mathrm{C}$ & 2.0 & 0 \\
Fused protoplast mixture & $\mathrm{A}$ & 2.0 & 0 \\
& $\mathrm{C}$ & 2.0 & 11 \\
& $\mathrm{~A}$ & 6.0 & 18 \\
& $\mathrm{C}$ & 6.0 & 13 \\
\hline
\end{tabular}

${ }^{2}$ Protoplasts obtained after electro protoplast fusion between $S$. sisymbriffolium and $S$. toxicarium.

y Protoplast density $=5.0 \times 10^{4} / \mathrm{ml}$.

${ }^{*}$ See Table 1.

the control plates of $S$. sisymbriffolium or $S$. toxicarium to the fusion plates, the rates of shoot and root formation of the fused protoplast-derived calli were similar to those of the parents (Table 5).

Isozyme pattern of PGD in 37 shoots forming roots was analyzed. Twenty four shoots regenerated from the calli cultured in medium A and 13 shoots in medium C showed the same isozyme patterns of the shoots of $S$. sisymbriifolium and S. toxicarium, respectively.

\section{Asymmetric protoplast fusion between $S$. sisym- briifolium and other Solanum spp.}

Cell division of $S$. sisymbriifolium, $S$. integrifolium and $S$. toxicarium protoplasts were completely inhibited by IOA of 7.5, 12.5 and $10.0 \mathrm{mM}$, respectively (Fig. 1).

The only fusion pair of $S$. sisymbriifolium and IOA treated $S$. integrifolium protoplasts resulted in the formation of five colonies, whereas the other pairs did not. Five calli (Table 6) were transferred to the regeneration medium to reduce shoot formation.

Isozymes for IDH, PGM and SKDH in the parentages of these five calli were analyzed before the shoot regeneration. Two calli were somatic cell hybrids (Fig. 2; data of PGM and SKDH not shown) while the others showed the same isozyme banding patterns as $S$. integrifolium. The shoots regenerated from the two somatic hybrid calli, however, showed one isozyme pattern, and it was

Table 3. Comparison of shoot formation from protoplast-derived calli and rooting of the shoots in S. sisymbriifolium, S. integrifolium and fused protoplast mixture ${ }^{z}$.

\begin{tabular}{|c|c|c|c|c|c|}
\hline \multirow{2}{*}{ Species } & \multirow{2}{*}{$\begin{array}{l}\text { Colony-induction } \\
\text { medium }\end{array}$} & \multicolumn{2}{|c|}{ No. of calli } & \multicolumn{2}{|c|}{ No. of shoots } \\
\hline & & Transferred & Forming shoots & Transferred & Forming roots \\
\hline S. sisymbriifolium & $\mathrm{A}^{\mathrm{w}}$ & 52 & $27(51.9)^{y}$ & 50 & $43(86.0)^{x}$ \\
\hline S. integrifolium & $\mathrm{B}$ & 52 & $23(44.2)$ & 48 & $39(81.3)$ \\
\hline \multirow[t]{2}{*}{ Fused protoplast mixture } & $\mathrm{A}$ & 13 & $6(46.2)$ & 28 & $20(71.4)$ \\
\hline & $\mathrm{B}$ & 280 & $98(35.0)$ & 210 & $173(82.4)$ \\
\hline
\end{tabular}

${ }^{2}$ Protoplasts obtained after electro protoplast fusion between $S$. sisymbriifolium and S. integrifolium.

${ }^{y}$ Percent calli forming shoots.

${ }^{x}$ Percent shoots forming roots.

${ }^{\mathrm{w}}$ See Table 1. 
Table 5. Comparison of shoot formation from protoplast-derived calli and rooting of the shoots in S. sisymbriffolium, S. toxicarium and fused protoplast mixture ${ }^{2}$

\begin{tabular}{|c|c|c|c|c|c|}
\hline \multirow{2}{*}{ Species } & \multirow{2}{*}{$\begin{array}{l}\text { Colony-induction } \\
\text { medium }\end{array}$} & \multicolumn{2}{|c|}{ No. of calli } & \multicolumn{2}{|c|}{ No. of shoots } \\
\hline & & Transferred & Forming shoots & Transferred & Forming roots \\
\hline S. sisymbriifolium & $A^{w}$ & 52 & $25(48.1)^{y}$ & 46 & $41(89.1)^{x}$ \\
\hline S. integrifolium & $\mathrm{C}$ & 52 & $16(30.8)$ & 30 & $30(100)$ \\
\hline \multirow[t]{2}{*}{ Fused protoplast mixture } & $\mathrm{A}$ & 18 & $11(61.1)$ & 29 & $24(82.8)$ \\
\hline & $\mathrm{C}$ & 13 & $5(38.5)$ & 14 & $13(92.9)$ \\
\hline
\end{tabular}

${ }^{z}$ Protoplasts obtained after electro protoplast fusion between $S$. sisymbriffolium and S. toxicarium.

y Percent calli forming shoots.

* Percent shoots forming roots.

${ }^{w}$ See Table 1.

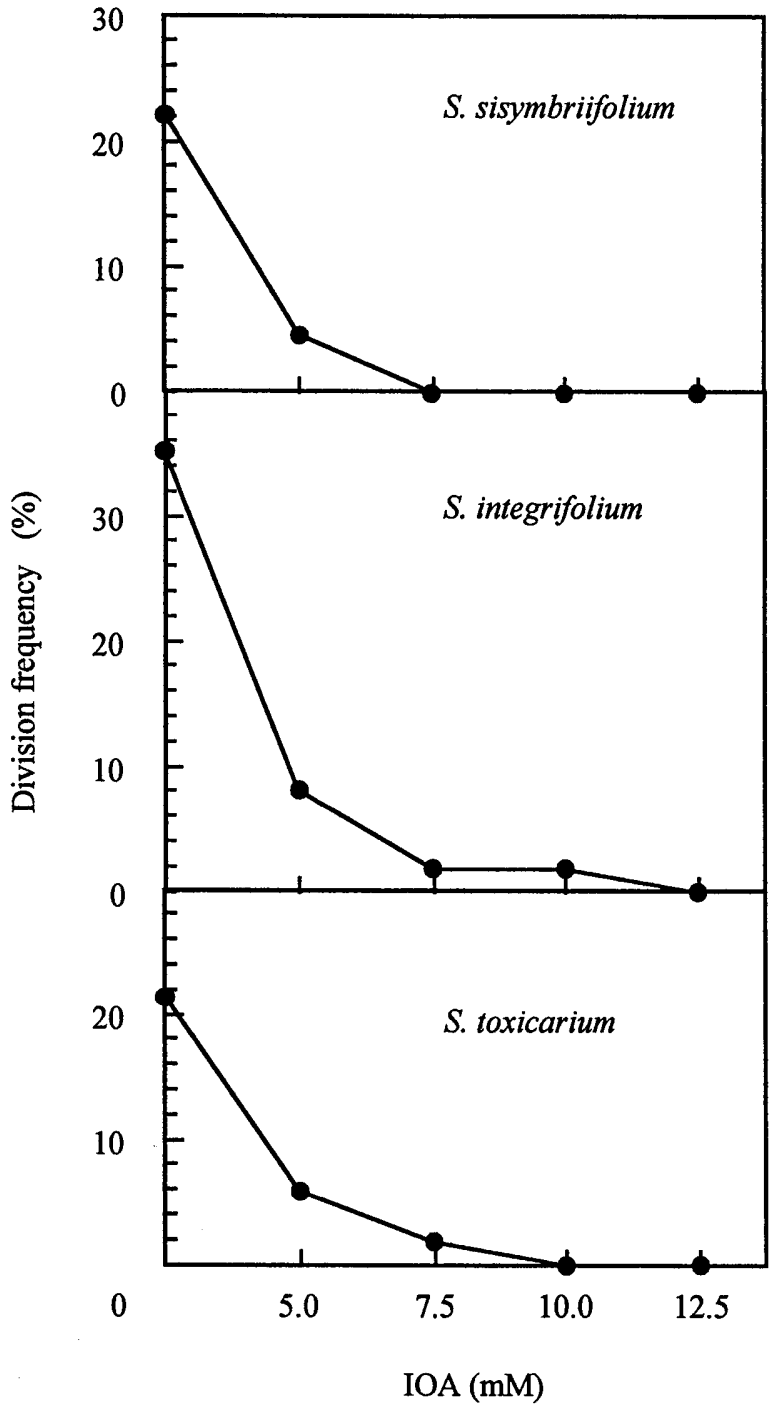

Fig. 1. Effect of IOA on the cell division of $S$. sisymbriifolium, S. integrifolium, and $S$. toxicarium.

the same as the pattern of $S$. sisymbriffolium (data not shown). The plants also had the similar morphology as $S$. sisymbriifolium, and died about four weeks after the shoot regeneration.

\section{DISCUSSION}

The present results indicate that the fusion rates of

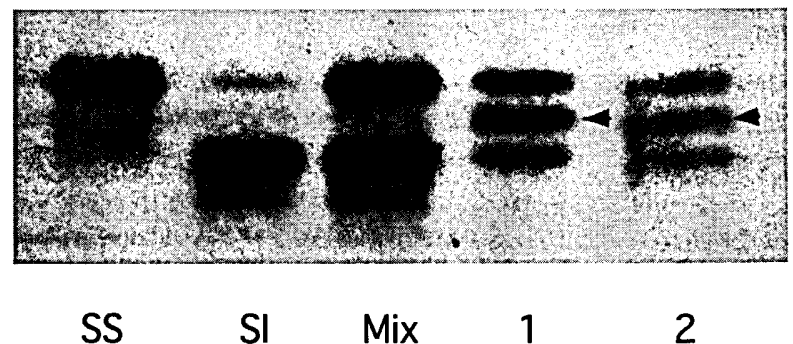

Fig. 2. Electrophoretic banding patterns of IDH isozymes, in leaf tissue of $S$. sisymbriffolium (SS), S. integrifolium (SI) and their mixture (Mix), and in calli of somatic hybrids ( 1 and 2). Arrows indicate heterodimer bands.

Table 6. Effect of media on colony formation from protoplast mixture fused between $S$. sisymbriifolium and $S$. integrifolium, and between $S$. sisymbriifolium and $S$. toxicarium.

\begin{tabular}{cccc}
\hline Species & Medium & $\begin{array}{c}\text { Cell } \\
\text { division }^{2}\end{array}$ & $\begin{array}{c}\text { No. of } \\
\text { colonies }\end{array}$ \\
\hline $\begin{array}{c}\text { S. sisymbrifolium* } \\
+ \text { S. integrifolium }\end{array}$ & $\mathrm{A}^{\mathrm{y}}$ & - & - \\
$\begin{array}{c}\text { S. sisymbriffolium } \\
+ \text { S. integrifolium* }\end{array}$ & $\mathrm{B}$ & $+(4)^{\mathrm{x}}$ & 5 \\
$\begin{array}{c}\text { S. sisymbrifolium } \\
+ \text { S. toxicarium }\end{array}$ & $\mathrm{A}$ & - & - \\
$\begin{array}{c}\text { S. sisymbrifolium } \\
+ \text { S. toxicarium* }\end{array}$ & $\mathrm{C}$ & - & - \\
\hline
\end{tabular}

${ }^{2}$ Volume of protoplast suspension $=6.0 \mathrm{ml}$, protoplast density $=5.0 \times 10^{4} / \mathrm{ml},+$ : Cell division, - : No cell division.

${ }^{s}$ See Table 1.

${ }^{x}$ Days to first cell divison.

* IOA treatment.
40-50\% were obtained in the first experiment, and they were similar to those in the fusion between $S$. integrifolium and $S$. toxicarium (Sadohara, 1993). Heterokaryon frequency was not determined since the protoplasts of the fusion partners were of the same type. At least $20 \%$ of the fusion products were estimated to be binary fusions. In a previous fusion experiment using the same electric apparatus (unpublished results) with 
green mesophyll protoplasts of $S$. integrifolium or $S$. toxicarium and colorless cell suspension protoplasts of S. sisymbriffolium, heterokaryons formed one quarter of the fusion products ( $50 \%$ fusion rate overall). At least $10 \%$ of the fusion products were, therefore, estimated to be heterokaryon. This frequency was $5-6 \%$ higher than that reported by Sadohara (1993) in the electro fusion between $S$. integrifolium and $S$. toxicarium protoplasts.

The selection of somatic hybrids by combination of media has been reported (Carson et al., 1972). In the present experiments, however, the medium for selection of only hybrid could not be found. But we found the media such as A, B and C where the protoplasts of one parent could form colonies and those of the other parent could not. It is unable to determine in these media whether the calli were from one parent or somatic hybrid but is possible to do that they were not from the other parent.

Isozyme banding patterns of the shoots regenerated from the calli cultured in the media A, B and C were identical to those of $S$. sisymbriffolium, $S$. integrifolium and $S$. toxicarium, respectivly, in symmetric protoplast fusion treatments. There are two possible reasons that the somatic hybrids could not be obtained. One is that the only one parent protoplasts divided but heterokaryons did not divide or not form colonies after division. The other is that the one parent's chromosome(s) in hybrid cell disappeared during mitosis at cell division or regenerating stage.

IOA treatment of the protoplast of one parental species ( $S$. integrifolium) was successfully combined with another untreated parent (S. sisymbriffolium) in the medium B. The IOA-treated protoplasts of $S$. integrifolium occasionally divided when they were cocultured with untreated protoplast of $S$. sisymbrifolium, even at the high IOA concentration enough to kill all the $S$. integrifolium protoplasts when cultured alone. This "nurse effect" of untreated protoplasts explains the appearance of an escaped callus of $S$. integrifolium even at the $12.5 \mathrm{mM}$ concentration of IOA (Fig. 1).

Inability of cell division of one parental species has been utilized for selection of somatic hybrids (Kameya et al., 1990). In this study, two calli that formed shoots were somatic hybrids, but the shoots regenerated from them showed the same IDH, PGM and SKDH isozyme patterns and morphology as $S$. sisymbrifolium did. This results may be caused by further elimination of $S$. integrifolium chromosomes in the plants regenerated from the hybrid calli, i.e., S. integrifolium chromosomes in hybrid cells disappeared during mitotic division at regenerating stage, because the parents' chromosomes were unbalanced. There are numerous reports that interfamilial or intergeneric somatic hybrids were genetically unstable and morphologically abnormal and showed the elimination of specific chromosome(s) and the disappearance of specific isozyme bands of a parent (Krumbiegel and Schiedr, 1979; Gleba and Hoffman, 1979, 1980; Chien et al., 1982; Niizeki et al., 1985; Gleba et $a l ., 1988$ ). It was considered that the similar phenom- enon occurred in this study.

Although the hybridity of the regenerated plants was not confirmed, somatic hybrid calli were produced. This suggests that the possibility of obtaining somatic hybrids between $S$. sisymbrifolium and other Solanum species, particularly $S$. integrifolium, by asymmetric protoplast fusion when subculturing system of asymmetric fused protoplast is established.

\section{ACKNOWLEDGMENTS}

The authors wish to express our sincere appreciation to Prof. Emeritus Dr. Kunimitsu Fujieda, Kyushu University for the valuable advice during this experiment.

\section{REFERENCES}

Ali, M. 1991 Breeding Eggplant Rootstock for Multiple Disease Resistance. Ph. D. Thesis, Kyushu University, Fukuoka, Japan

Ali, M. and K. Fujieda 1990 Cross compatibility between eggplant (Solanum melongena L.) and wild relatives. J. Japan. Soc. Hort. Sci, 58: 977-984

Ali, M., M. A. Quadir, H. Okubo and K. Fujieda 1990 Resistance of eggplant, its wild relatives and their hybrids to different strains of Pseudomonas solanacearum. Scientia Hortic., 45: $1-9$

Carson, P. S., H. H. Smith and R. D. Dearing 1972 Parasexual interspecific plant hybridization. Proc. Natl. Acad. Sci. USA, 69: $2292-2294$

Chien, Y. C., K. N. Kao and L. R. Wetter 1982 Chromosomal and isozyme studies of Nicotiana tabacum - Glycine max hybrid cell lines. Theor. Appl. Genet., 62: 301-304

Fassuliotis, G. and D. P. Bhatt 1982 Potential of tissue culture for breeding root-knot nematode resistance into vegetables. J. Nematol., 14: 10-14

Gleba, Y. Y. and F. Hoffmann 1979 "Arabidobrassica": Plant-genome engineering by protoplast fusion. Naturwissenschaft., 66: 547-554

Gleba, Y. Y. and F. Hoffmann 1980 "Arabidobrassica": A novel plant obtained by protoplast fusion. Planta, 149: 112-117

Gleba, Y. Y., S. Hinnisdaels, V. A. Sidorov, V. A. Kaleda, A. S. Parokonny, N. V. Boryshuk, N. N. Cherep, I. Negrutiu and M. Jacobs 1988 Intergeneric asymmetric hybrids between Nicotiana plumbaginifolia and Atropa belladonna obtained by "gamma-fusion". Theor. Appl. Genet., 76: 760-766

Kameya, T., N. Miyazawa and S. Toki 1990 Production of somatic hybrids between Solanum melongena $\mathrm{L}$. and $S$. integrifolium Poir. Japan. J. Breed., 40: 429-434

Krumbiegel, G. and O. Schieder 1979 Selection of somatic hybrids after fusion of protoplasts from Datura innoxia Mill. and Atropa belladonna L. Planta, 145: 371-375

Mochizuki, H. and H. Yamakawa 1979 Potential utilization of bacterial-wilt resistant Solanum species as rootstock for commercial eggplant production. Bull. Veg. \& Ornam. Crops Res. Stn. Japan, A6: 11-18 (In Japanese with English summary)

Murashige, T. and F. Skoog 1962 A revised medium for rapid growth and bioassays with tobacco tissue cultures. Physiol. Plant., 15: 473-497

Niizeki, M., M. Tanaka, S. Akada, A. Hirai and K. Saito 1985 Callus formation of somatic hybrid of rice and soybean and characteristics of the hybrid callus. Japan. J. Genet., 60: 81-92

Nishio, T., H. Mochizuki and K. Yamakawa 1984 Interspecific cross of eggplants and related species. Bull. Veg. \& Ormam. Crops Res. Stn. Japan, A12: 57-64 (In Japanese with English summary) 
Oda, N., S. Isshiki, T. Sadohara, Y. Ozaki and H. Okubo 2006 Establishment of protoplast culture of Solanum sisymbriifolium. J. Fac. Agr., Kyushu Univ, 51(1): 63-66. (In press)

Okimura, M., S. Matsuo, K. Arai and S. Okitsu 1986 Influence of soil temperature on the growth of fruit vegetable grafted on different stocks. Bull. Veg. \& Ornam. Crops Res. Stn. Japan, C9: 43-58 (In Japanese with English summary)

Rotino G. L., D. Perrone, P. Ajmone-Marsan and E. Lupotto 1992 Transformation of Solanum integrifolium Poir via Agrobacterium tumefaciens: Plant regenertion and progeny analysis. Plant Cell Rep., 11: 11-15

Sadohara, T. 1993 Studies on the breeding of Solanum species by protoplast fusion. Thesis of the Master Degree, Kyushu Univ., Fukuoka, Japan (In Japanese)

Sadohara, T., H. Okubo and K. Fujieda 1993 Plant regeneration from mesophyll protoplasts of Solanum toxicarium. Sci. Bull. Fac. Agr., Kyushu Univ., 48: 13-19 (In Japanese with English summary)

Schalk, J. M., A. K. Stoner, R. E. Webb and H. F. Winters 1975 Resistance in eggplant, Solanum melongena L. and nontuber-bearing Solanum species to carmin spider mite. $J$. Amer. Soc. Hort. Sci., 100: 479-481

Wendel, J. F. 1983 Electrophoretic analysis of genetic variation in wild and cultivated Camellia japonica L. Ph. D. Thesis, University of North Carolina, Chapel Hill, North Carolina

Wendel, J. F. and C. R. Parks 1982 Genetic control of isozyme variation in Camellia japonica L. J. Hered., 73: 197-204

Yamakawa, K. and H. Mochizuki 1979 Nature and inheritance of Fusarium-wilt resistance in eggplant cultivars and related wild Solanum species. Bull. Veg. \& Ormam. Crops Res. Stn. Japan, A6: 19-27 (In Japanese with English summary) 